In the great majority of cases, however, neither of these categories of change give heritable results. There are many other points of extreme interest to students of genetics; the chapter on variation and regulation in the production of ferments, for example, will be found specially suggestive, since here we appear to be dealing with one of the elemental phenomena of life, and a study of the genetic relations of these things is hardly possible in higher organisms. The author, however, rightly characterizes his book as chiefly a program for future work. A wellknown authority on bacteriology expressed to the reviewer his belief that results of great importance for the theory of genetics, such as the appearance of new heritable characteristics by adaptive change, can not be accepted with confidence from the study of bacteria, owing to the extreme difficulty of isolation, and the impossibility of following and identifying individuals and their progeny. Apparently the author of the present work is not so convinced that this difficulty is insuperable, and it has apparently been overcome in certain cases, as in the work of Barber. But a certain weakness in the positive conclusions to be drawn is here indicated, though this makes the book all the more inspiring to the man with the investigator's spirit, since it suggests to him many lines of work that can be carried out on the higher protista, where individuals can readily be followed and positively certain results reached. To all such, as well as to the general student of evolutionary problems, this book will be found of much value.

\section{H. S. JENNINGS}

The Coleoptera or Beetles of Indiana. By W. S. Blatchley. Bulletin No. 1, Indiana Department of Geology and Natural Resources. 8 vo, pp. 1,386, 590 figs. Indianapolis, 1910.

This volume is the first in America to deal with our native coleoptera in a comprehensive manner. There has been no single work to which one could resort for the determination of beetles, and this condition has com- pelled many to abandon the study of this important group of insects. The present work will, therefore, in a measure, supply a longfelt want; for, while ostensibly it treats only of the species found in Indiana, the majority of them are so widely distributed that it will be a most valuable aid in the determination of coleoptera from the eastern United States and Canada.

In this bulky volume all the Coleoptera, excepting the Rhynchophora, are treated. The familiar classification of LeConte and Horn is adhered to and accordingly the forms treated are divided into six series. There are identification tables for the families, tribes, genera and species. There are 2,535 species recorded as actually occurring in the state and 777 others which have been found in adjoining territory are added, and all these are included in the identification tables. Those known from the state are furthermore described and notes given on their regional and seasonal occurrence, and habits when known. A number of new species, scattered through the larger families, and one new genus are described. The new genus, Blanchardia, is placed in the Omethini, a tribe of problematic position but here referred to the Telephorinæ. The name Blanchardia has already been proposed for no less than four different genera; Blatchleya is proposed as a substitute for the present one. There are a goodly number of figures, not a few of them original, the remainder taken from all available sources. At the end is a glossary of technical terms, an index to the families and genera, and finally an index to the species described as new. Attention must be called to the fact that this last is not complete. There are omitted the species published under the manuscript names of others and described here for the first time and, therefore, to be credited to Professor Blatchley. Also the newly described varietal forms, for which trinomials are employed, should have been included in this index as some of them may, on further study, be raised to specific rank. It is possible that some of the forms described as new in the Staphili- 
nidø will interfere with those published recently by Colonel Thos. L. Casey. ${ }^{1}$ The names of Blatchley will, however, have priority, as his report was issued September 20 (received at the U. S. National Museum September 23), while Colonel Casey's paper has the date of issue September 24, 1910.

The task which Professor Blatchley set himself and carried to a finish is gigantic and one is filled with admiration for the energy, perseverance and enthusiasm which alone could have carried it through. Any one at all familiar with the multiplicity of forms in the Coleoptera, and the extensiveness of the literature, will realize the labor involved. In this case it must have been very materially augmented by the fact that Professor Blatchley lives remote from large libraries, collections and fellow-workers.

That there are shortcomings and errors in a work of such scope, carried out single-handed, must be expected. Some of these are due to the fact that the author has had to depend for the most part on the current American entomological literature. Thus Smilia in the Coccinellidæ is preoccupied and replaced by Microweisea Cockerell. Gahan has shown that in the cerambycid genus Cyllene the names robinice and pictus both apply to the same species and for the form occurring on the hickory the name caryos was proposed. Systematically'the work reflects closely the present state of North American coleopterology. While there has been great activity in the description of new species and genera the broader study has been practically neglected since the days of LeConte and Horn; no attempt has been made by our students to follow the progress of the science abroad. Thus the position of the Rhyssodidm in the adephagous series has long been an established fact. The grouping of the families has, for good reasons, been very much modified in recent years and the conception of certain families has entirely changed.

Perhaps the greatest weakness of the work is on the biological side, and this too indi-

1 " Memoirs on the Coleoptera," I. cates the backward state of our knowledge on this side of the Atlantic. There are many statements concerning habits and larval characters which need correction. The Clavicornia are broadly stated to be scavengers, whereas, in fact (and in accordance with the heterogeneous character of the group as here considered) their habits are most diversified. In the Silphidæ both the genera Necrophorus and Silpha are said to bury dead animals, but this is only true of the first-named genus. Some mention should also have been made of the habits of the smaller forms which are now generally considered to belong to two separate families, the Liodidæ (Anisotomidæ) and the Clambidæ. Of the Staphylinidæ the broad statement is made that "they feed upon decaying animal and vegetable substances." This is probably true of but a small part of this large group, as many widely separated forms have been shown to be predaceous both as imagos and larvæ. A very loose statement concerning staphylinid larvæ is that they, "except in the absence of wings, resemble the adults both in structure and habits." Under the elaterid genus Melanactes the old error with reference to the luminous female and larva (the two being identical in structure) of Phengodes is perpetuated, and this in spite of the fact, as appears from the text, that Mr. Henshaw advised the author of the true relation of these forms. Many of the original figures, while fairly faithful in detail, are not characteristic and give a wrong impression of the habitus of the insects. This can not be wondered at when one considers the difficulty of securing competent talent for such work. In this respect the unexcelled figures from the reports of Forbes, which are reproduced, are in striking contrast.

In the introductory part of the work Professor Blatchley tells us that the Rhynchophora are not included on account of lack of time and space, but the hope is held out that a future report will be devoted to thern. We understand that Professor Blatchley not only has the necessary collections at hand but that he also has the manu- 
script partly prepared. It is therefore to be hoped that this part will soon follow and thus the entire order of Coleoptera be covered.

The edition was limited to one thousand copies and, we understand, is practically exhausted. It is to be hoped that a revised edition, in generally available form, will soon be forthcoming. With the general demand for a work of this character there should be an extensive sale for the work for many years to come.

Frederick Knab

Leitfaden der experimentellen Psychopathologie. Von Adalbert Gregor. Pp. 222. Berlin, S. Karger. 1910. M. 6.80 .

In this book the author attempts to give, in a series of sixteen lectures, the applications of the methods of experimental psychology to the study of mental diseases. Considering the limited amount of literature of experimental psychopathology, and the still more limited extent of its established fact, it would appear a difficult task to produce a book of such scope with strict adherence to its subject, nor is it accomplished save through the inclusion of much detailed analytical discussion. The single topics are treated quite distinctly in the successive lectures, and in another edition it will be well if page and chapter headings are provided for the text and bibliography. A very critical introductory chapter is followed by another of equal merit on the time sense, of which the author has himself made some pathological studies. The chapter on reaction time is also well constructed, but these three lectures set a standard that is scarcely reached elsewhere in the book, save perhaps in the seventh and eighth, on memory, and in the fourteenth, on the involuntary expressive movements. The chapters on association give only the merest elements of the question at issue, and the two chapters on Aussage might well have been condensed. One might, as a psychopathologist, also criticize the sense of proportion that gives two indifferent chapters to Aufmerksamkeit and but one to voluntary movement-practically confined to discussion of the ergograph and the Schriftwage. The questions of the work-curve in the higher mental processes are discussed in the fifteenth lecture, while the last deals with measures of intelligence-without a mention, even bibliographical, of Binet and Simon.

The seven pages of bibliography are nevertheless useful, for while they omit a good deal that the psychologist would ordinarily know of, as Hoch's pathological work with the ergograph, the studies of Kramer and of Wolfskehl on memory, and of Vogt or Alechsieff on feeling, it contains a good many titles of importance not apt to be familiar to the worker whose horizon does not extend well beyond the literature of normal psychology; examples are the too little known studies of Ranschburg on memory, and the various papers of Gregor himself.

In a general treatise, equal merit throughout could be achieved only by an equal lack of it, and the author has probably done what he tried to do as well as any single writer on the hither side of Kraepelin could have done it. And yet the book suffers from an underlying fault in conception that to the psychopathologist will go far indeed to outweigh all its virtues. It is the last weakness that one would expect in a physician, accustomed to clinical contact with actual cases. The book seeks not only to translate the methods of normal psychology into pathological terms, but also its problems. Now normal psychology has its well-defined problems, as the reader of this journal knows them, but it recks little of such pressing questions of psychopathology as the experimental criterion of confusion, the distinction between retardation and blocking, or the differential psychology of hallucinosis. To the psychological reader, the volume would scarcely give a hint that such questions existed. It is a doubtful service to explain how various methods of normal psychology, adapted to its own special problems, can be tried on pathological cases, too. It were a very real service to discuss the various psychotic symptoms in their appropriate clinical settings, and to explain the application of psychological methods to their further elucidation. Here the book fails grievously; and one can not but 